\title{
Verkondig Christus totdat hy kom! Die huidige denke binne die Evangeliese Beweging
}

\author{
J J Kritzinger \\ Universiteit van Pretoria
}

\begin{abstract}
World evangelisation within the Lausanne movement
\end{abstract}

This article considers a number of key themes regarding world evangelisation. The point of departure is the second general conference of the Lausanne movement, which was held in Manila during July 1989. The first section gives some background to the Lausanne movement and events leading to this large and representative gathering. Secondly, some personal impressions gained at the conference itself are related. This is followed by a section on the Philippine setting of the conference, which played an important role in creating an atmosphere of involvement with the real world. The last section deals with some of the important issues arising from the conference. What should the future agenda be for world missions?

\section{DIE LAUSANNE BEWEGING}

Alhoewel die Wêreldraad van Kerke (WRK) eers in 1948 tot stand gekom het, was die sterkste stimulus vir die ekumeniese beweging die Internasionale Sendingraad (ISR) en die sendingbewe ging in die algemeen, wat in 'n reeks groot konferensies sedert 1910 baie gedoen het om die gedagte van ekumeniese samewerking te laat posvat. In 1961 het hierdie (evangeliese) sendingstroom by die WRK aangesluit, in die hoop dat dit die hoofstroom in die rigting van evangeliese betrokkenheid by die wêreld sal beïnvloed.

Reeds in die laat sestiger- en vroeë sewentigerjare het daar egter toenemende kommer onder baie Christene en sendingmense uit die eertydse ISR begin ontwikkel oor die rigting wat die gesamentlike ekumeniese beweging begin inslaan. Veral was 
daar ontevredenheid oor drie aspekte:

- Dit het gelyk asof die WRK 'n nuwe humanistiese teologie aanvaar het, 'n teologie wat gelei het tot sodanige politieke en maatskaplike betrokkenheid dat die wesenlike van die evangelie, die (vertikale) verhouding, en die oproep tot persoonlike bekering tot God, verdring is.

- Hierdie teologie het geneig tot 'n relativisme en universalisme wat nie anders kon as om die kerk se sendingaksie te verlam nie. Die evangelie van Christus sou eenvoudig nie meer as die unieke weg van verlossing aangebied kon word nie. Die skuldgevoel van die Weste oor die onreg van die koloniale en neokoloniale tyd het die (Westerse) kerk gaandeweg die vrymoedigheid ontneem om nog met evangelisering en kerkplanting in die nie-Weste voort te gaan.

- Die gevolg hiervan was dat die Westerse kerk sodanig met homself en sy eie skuld behep begin raak het, dat hy selfs onseker was oor sy eie fondamente. Die evangeliese mense het begin meen dat die driekwart van die wêreldbevolking wat nie Christene was nie, en in besonder daardie helfte wat nog glad nie met die evangelie bereik was nie, deur die ekumeniese kerke 'verraai' word.

Hierdie 'verontrustes' sou kom uit die kringe van die sogenaamde evangelicals," mense wat - in teenstelling met die tendense hierbo aangedui - beskryf word as mense wat gekenmerk word deur dinge soos (i) 'n onwrikbare geloof in die outoriteit van die Skrif, (ii) die noodsaaklikheid van persoonlike bekering, en (iii) die onvervreembare opdrag om die evangelie aan alle mense uit te dra. Die grootste deel van die praktiserende Protestantse sendelinge sou waarskynlik as evangelicals kon deurgaan. Tog sou hulle onderling nog ' $n$ wye spektrum opinies oor allerlei leerstellige sake verteenwoordig. Sommige sou sterk aan die groot doop glo en ander nie; sommige sou as Pinkster of Charismaties bestempel kon word en ander heftig daarteen gekant wees; sommige sou sosiaal sterk betrokke wees, en ander meen dat dit die evangelie sou kompromitteer.

Hierdie diffuse groep mense sou, grootliks deur die bemoeienis van die alom gerespekteerde senior evangelis Billy Graham, in 1974 te Lausanne byeengebring word in die 'International Congress on World Evangelization' (ICOWE), met nagenoeg 2500 deelnemers uit meer as 150 lande. Alhoewel daar mense binne die evangeliese stroom was wat nie hiervoor kans gesien het nie, sou hierdie tog die mees

- Die definisie van hierdie groep is mocilik en ek gaan dit ook nic hier probeer weergee nie. Wel kan ek verwys na 'n bock wat pas verskyn het en feitlik 'n 'amptelike' geskiedenis verteenwoordig: Allan, J D 1989: The evangelicals: The story of a great Christian movement. London: Paternoster. 
verteenwoordigende evangeliese byeenkoms tot op daardie datum wees. Afgesien van die prestasie om so 'n groep byeen te kry, is daar in die kongres onder die oorkoepelende tema Let the earth hear His voice, besonder belangrike informasie en insigte deurgegee, konsepte wat die voortgaande evangelisering van die wêreld ingrypend sou beïnvloed. Die tientalle groter en kleiner referate en reaksies is in 1471 bladsye gepubliseer (Douglas 1975), 'n boek wat steeds 'n myn van informasie bly.

Daar was ten minste twee belangrike praktiese gevolge van hierdie kongres:

- In die eerste plek is die Lausanne covenant onder leiding van John Stott opgestel, 'n teologiese dokument wat in 15 artikels (3000 woorde) ' $n$ ireniese, maar besliste uiteensetting gegee het van die sake wat vir die evangeliese Christen basies is. Hierdie dokument is bespreek en uiteindelik deur die aanwesiges plegtig onderteken. Die Lausanne Covenant is uitendelik ook ver buite die evangeliese kring as 'n besonder betekenisvolle dokument erken en het in 'n mate teologiese statuur aan die beweging verleen. Tot vandag toe staan dit as die basis van die Lausanne- en die evangeliese beweging.

- Die ander praktiese besluit was om 'n voortsettingskomitee, die 'Lausanne Committee for World Evangelization' (LCWE) in die lewe te roep. So kon die sogenaamde 'Lausanne-beweging' tot stand kom wat, alhoewel daar geen lidmaatskap is nie, tog deur die LCWE gekoördineer sou word. As eerste Internasionale Direkteur is Gottfried Osei-Mensah benoem, 'n Ghanees van geboorte, maar met baie internasionale ondervinding as sakeman, jeugwerker en later leraar. Ongeveer 10 jaar later het hy uitgetree en is hy opgevolg deur 'n Sjinees, in Sjina gebore maar tans ' $n$ burger van die VSA, Thomas Wang, ' $n$ leier in teologiese opleiding. Die organisasie van die volgende groot konferensie in Manila (die aanleiding vir hierdie artikel) sou op sy skouers rus. Tydens daardie vergadering is aangekondig dat Tom Houston, 'n Skot met' $n$ besondere loopbaan as leraar in Nairobi, Bybelgenootskapman in Brittanje en internasionale leier van World Vision, vir Wang sal opvolg wanneer hy na sy eerste liefde terugkeer.

Die gevaar was groot dat die Lausanne-beweging bloot 'n opposisieliggaam vir die WRK sou word. Sommige wou dit so hê, maar gelukkig het die leierskap dit nie toegelaat nie. Die administrasie sou eenvoudig en klein bly en hoofsaaklik 'n skakel- en stimuleringsfunksie hè. Die twee entiteite - die evangeliese en die ekumeniese - sou 'n versigtige kritiese verhouding behou. Verskillende persone het egter aktief in beide evangeliese en ekumeniese kringe gebly, en so die lewende 
brug tussen die twee beklemtonings gevorm. Daar sal later teruggekeer word na die vrugte van hierdie verhouding.

Deur bemiddeling van die Lusanne-komitee is reeds verskeie streeks- en tematiese kongresse rakende wêreldsending en -evangelisasie gehou, wat weer die stimulus vir ander inisiatiewe kon word. Ook is 'n aantal persone onder die LCWE sambreel beklee met die status van 'Lausanne Associates'. Hulle, tesame met die 'Task Groups' wat om hulle versamel is, sou nadenke oor die verskillende spesialiteitsvelde aan die gang hou. Na vyftien jaar was die tyd dus ryp om weer eens 'n algemene konferensie, soos die eerste in Lausanne, te hou.

\section{DIE BYEENKOMS: LAUSANNE II IN MANILA}

'n Beginselbesluit is geneem dat die byeenkoms in die Derde Wêreld (in evangeliese kringe word verkieslik gepraat van die Tweederde Wêreld) gehou moes word. Toe probleme met die fisiese fasiliteite te Singapore ondervind is, is besluit op die indrukwekkende monument van Imelda Marcos: die 'Philippine International Convention Center', deel van die kulturele kompleks op 'n drooggelegde deel van Manilabaai.

Daar is ook besluit dat streng vereistes vir keuring voorgelê sou word om te verseker dat die armer lande, die vroulike en jonger geslag, en nie-predikante voldoende verteenwoordig sou wees. Die samestelling van die nasionale groepe is, onderhewig aan hierdie riglyne, aan plaaslike komitees oorgelaat.

Dit is belangrik om te verstaan dat daar in die Lausanne-beweging, anders as by die WRK waar alleen afgevaardigdes van kerke en streeksorganisasies stemreg het, steeds van deelnemers en op geen manier van 'afgevaardigdes' sprake was nie. Die individue het nòg hulle kerke nòg hulle organisasies verteenwoordig en kon gevolglik op 'n baie ontspanne wyse met mekaar verkeer. Dit is 'n model van ekumeniese samesyn wat sorg vir onvergelyklike broederlike samesyn en ' $n$ besondere gevoel van eenheid. Op die voor-en nadele van hierdie model kom ons later terug.

Hoe dit ook al sy, daar is aanspraak daarop gemak dat nie minder nie as 191 lande daar verteenwoordig is - die mees verteenwoordigende vergadering ooit! Die mees tragiese was die afwesigheid van die meer as 300 persone uit die Volksrepubliek van Sjina wat sou kom, maar weens die tragiese gebeure op Tiananmenplein nie deur hulle regering toegelaat is om te vertrek nie. Baie emosies is hieroor losgelaat, en 'n afgekampte gebied binne die vergadersaal het almal aan die leë stoele herinner. Die Russiese afvaardiging is met groot simpatie verwelkom. Die Suid-Afrikaners het, ná die gewone visumprobleme, net liefde en begrip ervaar. (Die enigste krapperigheid en gebrek aan hartlikheid was binne die Suid-Afrikaanse 
afvaardiging! Ons kan maar nie ons Suid-Afrikaanse bagasie tuis laat nie!)

Die program was besonder deeglik beplan en met behulp van die jongste tegnologie met goeie effek aangebied. Moeite is gedoen om te verseker dat die sprekers nie eensydig uit Noord-Amerika en Europa genooi sou word nie. Die lys het uiteindelik ook heelwat Asiërs, Afrikane, mense uit die Stille Oseaan eilande, en SuidAmerikaners ingesluit. Daar was ook vertalingsfasiliteite in 'n hele aantal tale. Wat die byprogram betref, was daar pragtige bydraes van Thai dansers en 'n dramagroep, 'n Filippynse mimiekkunstenaar en koor, en 'n gemengde ensemble. Nogtans het die byeenkomste 'n oorweldigend Engelstalige en Noord-Atlantiese stempe] gedra.

In die oggend en in die aande is volsessies gehou. Die subtema van die kongres - 'Calling the whole church to take the whole gospel to the whole world' - het die oorkoepelende temas van hierdie sessies geword.

- Die eerste oggendsessie het gestaan in die teken van die 'whole gospel'. Na die daaglikse Bybelstudie (oor Romeine) is aspekte soos 'good news for the poor', 'sin and lostness', 'gospel and salvation', 'cross-cultural evangelism' en 'cooperation in evangelism' behandel.

- Na tee is 'n paar groot sake rakende 'the whole world' aangeroer. Dit was agtereenvolgens 'the challenge before us', 'urban evangelism', 'the impact of modernization' (met Os Guinness se referaat miskien die intellektuele hoogtepunt van die kongres), 'social concern and evangelism', 'the uniqueness of Christ', 'communication and evangelism', 'commitment and sacrifice' en 'preparation for the future'.

- Saans was die tema 'the whole church'. 'The primacy of the local church', 'the mandate of the laity', die kontroversiële 'power and work of the Holy Spirit in evangelism', 'evangelizing in challenging settings' en 'AD 2000 and beyond' is dan behandel.

Die namiddae is gewy aan die keuse-sessies. Daar was nie minder nie as veertig 'tracks' - myns insiens onnodig baie - waaruit 'n keuse gemaak kon word, met die moontlikheid om 'n aantal van hulle te kombineer vir maksimum verryking. Daarbenewens het die nasionale groepe die geleentheid gehad om vir ten minste 5 ure saam te beraadslaag oor die verdere evangelisering van hulle land. Hierdie kleiner groeperinge kon benut word om dieper op bepaalde sake in te gaan en om kontak te maak met leidende denkers in daardie rigting.

Talle organisasies het gebruik gemaak van die geleentheid om deur middel van uitstallings hul literatuur en programme bekend te stel. Heelwat van die jongste 
inligting is so beskikbaar gemaak.

Daar is (wyslik) aangekondig dat die Lausanne Verbond nie hersien gaan word nie. Alhoewel allerlei mense waarskynlik hier en daar wysinge sou wou voorstel, was daar tot so 'n mate instemming daarmee dat dit onveranderd as basis behoue bly. Trouens, die deelnemers aan die konferensie het dit reeds vooraf as basis aanvaar. Daarom het die besluitekomitee, weer eens onder leiding van die bekwame John Stott, hulle daarop toegespits om die Lausanne Covenant net hier en daar an te vul, enkele sake verder te voer, en iets op te som van die inhoud en gees van die vergadering. Halfpad deur die kongres is toe na vore gekom met 'n konsep Manila Manifesto, met die versoek dat groepe en individue skriftelike kommentaar daarop moes indien.

Nadat al hierdie kommentaar verwerk is, met die uitgesproke doel om die middeweg te volg, is daar toe op die voorlaaste dag ' $n$ finale stuk uitgedeel. Dit is nooit tot bespreking gebring, of punt vir punt goedgekeur nie, maar is deur die hele vergadering met entoesiasme aanvaar as, in die breë, ' $n$ uiteensetting waarmee hulle hul kan identifiseer.

\section{MANII A AS KONTEKS VIR DIE KONGRES}

Die beskuldiging word dikwels gemaak dat die spanning tussen 'ecumenical' en 'evangelical' ' $n$ intern Westerse saak is wat aan die Christene van die res van die wêreld opgedring word. Die kerke van die Derde Wêreld is inherent evangelies, omdat hulle grootliks die produk van evangeliese sendelinge is. Maar hulle is ook in beginsel ekumenies, omdat die probleme waarmee die ekumeniese stroom worstel, hulle daaglikse uitdagings is. 'n Eksklusiewe evangeliese beweging is dus vir hulle irrelevant en vreemd. Die Lausanne beweging het hierdie kritiek klaarblyklik ernstig geneem en daarom besluit om die oorheersende invloed van die Westerling teen te werk. Die Lausanne komitee het as beginsel aanvaar dat die volgende byeenkoms iewers in die Tweederde Wêreld moes plaasvind, en dat nie-Westerlinge 'n veel groter rol daarin moes speel. Dit sou die reëlings geensins makliker maak nie, en ook nie noodwendig goedkoper nie, maar dit was simbolies belangrik.

Dat dit uiteindelik in Manila aangebied is, het myns insiens in ' $n$ groot mate hygedra tot die waarde van die konferensie. Hierdie stad is een van die groot stede van die Derde Wêreld, en 'n stad waarin al die tipiese kenmerke opsigtelik is. Daarby is die Filippyne een van die Derde Wêreld lande wat baie aandag geniet weens die politieke ontwikkelinge van die jongste tyd. Hierdie keuse het dus meegebring dat die minder aangename werklikhede van die groter wêreld onvermydelik op die konferensietafel sou beland. Dit sou nie bloot 'n Westerse konferensie kon 
wees nie. In die eerste plek het die kontraste almal aangespreek.

* Die deelnemers aan die koferensie het tuisgegaan in luukse hotelle - van die soort wat enige plek ter wêreld op ryk toeriste wag. Die konferensiesentrum was van 'n imponerende gehalte, wat nie orals ter wêreld beskikbaar is nie (in ieder geval nie in Suid-Afrika nie). Soos reeds gemeld, was hierdie die erfenis van die hoogs kontroversiële Marcos regime, 'n regeringstyd wat gekenmerk is deur grootse pogings om hierdie arm land selfrespek te gee deur hom te laat lyk na 'n ryk land. Dat meeste van die 'ontwikkelingsgeld' afkomstig van die Weste tog maar indirek in die sakke van reeds rykes - en van die regeerders self beland het, is ongelukkig waar, maar nie uniek in die ontwikkelende wêreld nie.

Rondom hierdie luukse simbole was die werklikheid van intense armoede en tragiese ontreddering egter onmoontlik om mis te kyk. Die strate was vol armes wat op allerlei wyses probeer aan die lewe bly. Enige rit het verby plakkerbuurtes gelei, letterlik in die skaduwee van die luukse hotelle. Huislose, weerlose mensies slaap tot op die buitetrappe van die hotelle. Ongeveer $40 \%$ van die nagenoeg 10 miljoen inwoners woon in die sowat 400 plakkergebiede van Manila. Uitstappies sou ook plekke soos 'Smokey Mountain', 'n gemeenskap van 50000 mense wat op en van een van Manila se vullishope leef, insluit. Al die werklikhede van die armoedeprobleem van die wêreld het hom aan elke konferensieganger opgedring.

Die rykdom en armoede, so direk langs mekaar, sou die gevoelige besoeker nie onaangeraak laat nie. Is dit nie maar 'n mikrokosmos van die hele wêreld nie? En dít is die wêreld waarbinne die 'evangelie aan die armes' gekommunikeer en waargemaak moet word!

- Die Filippyne het die afgelope vier jaar in die brandpunt van internasionale aandag te staan gekom weens die epiese stryd van die volk om hulle eie demokratiese keuse te laat geld teenoor die magsbelustheid van (die intussen oorlede) president Ferdinand Marcos en sy vrou Imelda. In Augustus 1986 het 'n skare van miljoene mense op die EDSA Boulevard saamgedrom en geweier om die uitslag van die presidentsverkiesing, waarvolgens Marcos vir mevrou Corazon Aquino (die weduwee van die vermoorde leier van die opposisie) verslaan het, te aanvaar. Oprukkende tenks was magteloos teen die knielende nonne en biddende skares. Binne 48 uur was Marcos 'n balling en 'Cory' die president! 'n Nuwe konsep is gebore: peaceful people power revolution, 'n oorwinning vir die klein mens teen die magtiges. Die euforie oor 'hulle' revolusie is nog steeds merkbaar. Die mense beweeg in hulle stad rond met 'n 
vryheid en selfstandigheid wat verras.

Revolusies en magsoornames is ook deel van die werklikheid in die wêreld. Is die Filippynse model - waar die kerk en gebed agter die vreedsame protes was - dalk die antwoord ook vir ander wêrelddele (soos, mag ons byvoeg: SuidAfrika)? Ongelukkig is die korrupsie en magsbelustheid nog glad nie uitgeskakel nie, nòg is die kloof tussen ryk en arm oorbrug. Selfs president Aquino, ongelukkig behorende tot een van die rykste families in die Filippyne, het nog nie van haar eie persoonlike geldmag afstand gedoen nie. Die hemel op aarde het toe nie aangebreek nie. 'n Gevaarlike frustrasie van onbevredigde verwagtings begin reeds onder die oppervlak smeul. Die plek van die konferensie het dus onvermydelik veroorsaak dat die politiek nie misgekyk kon word nie.

- Die aangename en hartlike vriendelikheid wat die besoeker aan Manila so tref, is daagliks gedemp deur die berigte in die pers, en die algemene gerugte wat die omloop doen, van moord en roof, verdwynings en gewelddadige optrede van beide die kommunistiese rebelle en die regeringsmagte. Geen gebou en winkel in die stad het nie sy eie (vriendelike) wagte in blou uniforms nie. Sekuriteit in die vergadering was uitermate streng.

Soos orals in die Derde Wêreld broei daar iets in die gemeenskap. Die hoë bevolkingsaanwas, die gebrek aan werkgeleenthede, die uitsigloosheid van sowel die bestaan op die platteland en die oorlewingstryd in die stad met sy samedromming, dit alles is die werklikheid waarmee regeerders rekening moet hou. Ten spyte van mooi beloftes en geesdriftige aankondigings begin ook Cory Aquino agterkom dat die oplossings nie so eenvoudig is nie.

Hierdie indrukke is ook op besondere wyse onderstreep deur die deelname van 'n paar besondere Filippinos aan die konferensie.

* President Aquino kon ongelukkig nie self die geleentheid bywoon nie (sy was op 'n toer deur Europa om 'ontwikkelingshulp' te werf), maar die president van die Senaat, Senator Jovita Salonga het die deelnemers op die eerste oggend verwelkom. Hy het onder andere melding gemaak daarvan dat, hoewel die Filippyne bekend gestaan het as die enigste Christelike nasie in Asië, dit ook bekend was as die mees korrupte! En dit, sê hy, terwyl die Christendom en korrupsie 'incompatible' is! Hy het ook met groot emosie verwys na die moord, twee weke vroeër in die suide van die land, op 'n hele gemeente van 47 lede van sy eie kerk, die United Church of Christ in the Philippines, deur kommunistiese insypelaars. Dit, het hy gesê, is die konteks waarbinne die evangelie vandag 
verkondig moet word. Hy het afgesluit met die treffende versoek: 'Pray that the weak shall be strong, and the strong just!'

- 'n Ander deelnemer was 'n jong sanger met die naam Gary Granada, wat uit Christelike oortuiging die wantoestande in die land deur middel van populêre protesliedjies uitspel. Een van sy liedere, 'Bahay' (Tagalog vir 'huis') word hier in Engels weergegee:

\section{HOUSE}

One day I visited a 'house' on the garbage dump.

Squeezed inside was a household of fifteen people, enduring a small, make-shift, broken down shanty while a nearby mansion was almost empty.

Imprisoned inside wooden slabs and corrugated boxes, shaded by rustic zinc sheets and worn out tires, mended together by scraps of trash and held down by stones. I could not understand why such a thing is called a house.

I decided to write a story about what my eyes saw, and even made a song that others may hear and know. I painted what I felt and put up a simple play, and asked knowledgeable people what they can say.

A famous senator was the first person I came to see, and then an expert professor of a prominent university, and a blessed businessman, and the newsman and the pulpitman, and they all agreed that, indeed, it was a house.

Day and night they scrape off the mountain of trash, and eat like chickens on the floor as they squat.

And force their bodies to sleep on an old torn bed far better is the resting place of the dead.

And if one day you'll accidentally pass by that place, and feel and hear and smell and see them face to face I do not mean to deride - I leave it for you to decide: do you think that in the eyes of the Creator this is a HOUSE? 
- 'n Laaste saak wat genoem moet word, is die nie-deelname aan die konferensie van die plaaslike Rooms-Katolieke Kerk. Die Filippyne is oorweldigend Rooms-Katoliek, 'n resultaat van die meer as 400 jaar lange Spaanse kolonisasie. Die kerk het nie alleen 'n baie sterk historiese posisie in die harte van die mense nie, maar was ook op die voorpunt van die revolusie. Die kerk het dus baie mag. Tog het daar in die jongste jare sterk groei voorgekom onder die sogenaamde 'born-again' beweging, deur die Rooms-Katolieke Kerk ook die 'fundamentalists' genoem. Alhoewel hierdie interne spanning nooit in die konferensie ter sprake gekom het nie, kon in die koerante gelees word dat die Rooms-Katolieke hierargie besluit het dat dit nie 'prudent' sou wees om mee te doen, of selfs 'n woord van verwelkoming te spreek nie. Inteendeel, die charismatiese vertakking van die kerk het op die Sondag tydens die konferensie 'n baie groot saamtrek in Rizalpark gehou, as 'n duidelike teenvoeter vir die aandag wat die 'fundamentalists' getrek het. Dit was natuurlik baie jammer, maar ook 'n refleksie van die werklikheid: die liggaam van Christus gaan die wêreld daarbuite erg verdeeld tegemoet.

\section{'N PAAR BELANGRIKE SAKE}

Hierdie konferensie was verteenwoordigend van een van die heel belangrikste en vitaalste strominge in die Christenwêreld, en baie van die mees vooraanstaande Christelike denkers van vandag was fisies teenwoordig. Dit sou dus in allerlei opsigte as 'n laboratorium vir tendense benut kon word. Slegs 'n paar sentrale sake word uitgelig.

\section{Charismatici}

Soos reeds gemeld, het die Lausanne-beweging nog die naaste daaraan gekom om die wyd geskakeerde evangeliese stroom onder een noemer byeen te bring. Daar is egter nog steeds 'n wye verskeidenheid binne die beweging, wat wissel tussen die werklik fundamentaliste (wat sterk staan op die letter van die Skrif) en die konfessioneel konserwatiewe mense, die groepe wat die Gees absoluut in die middelpunt stel verby, tot by die radikale, verontruste, sosiaal betrokke 'new evangelicals'.

Een van die belangrikste verdelings wat binne die evangeliese beweging loop, is dié tussen die Charismatici/Pinkster-geneigdes en die meer 'ortodokse' gelowiges. Daar was aanduidings dat hierdie spanning op sommige plekke baie ernstig beleef word. Voordat hierdie onderwerp tydens 'n aandsitting aan die beurt gekom het, het die voorsitter, Leighton Ford, in 'n inleiding beklemtoon hoe belangrik dit is om die eenheid te behou te midde van verskil van opinie. Omdat daar skerp reaksie 
was op die twee toesprake wat die twee beklemtonings verteenwoordig het, was dit weer Ford se taak om olie op die omgekrapte waters te gooi. Sy betekenisvolle woorde was: Miskien sal Lausanne II veral onthou word vir die mate van eenheid wat tussen Charismatici en nie-Charismatici in die evangeliese beweging bereik is!

Mag dit wel die geval wees dat hierdie ongelukkige spanning opgelos word, maar vir ons uit die Tweederde Wêreld was hierdie saak 'n ietwat te hoog opgegee. Dit is (gelukkig) nie by ons die hoogste prioriteit nie (of is dit?).

\section{Eenheid}

Dit sou vreemd wees as die missionêre dimensie van die kerk se bestaan nie op hierdie konferensie die beklemtoning geniet het nie. Wanneer daar byvoorbeeld oor die plaaslike gemeente gepraat is, was dit in die konteks van die kerk-as-diedraer van die evangelie. Wanneer daar oor die lidmaat (laity) gepraat is, was dit om sy taak en geleenthede vir evangelisasie uit te spel. Omdat die klem sterk geval het op die taak wat verrig moes word, is die hoogs kontroversiële verhouding tussen 'kerk' en 'para-kerk' eintlik net binne die konteks van die gesamentlike taak behandel. (Dalk is die evangeliese beweging te veel deur die vryemark sisteem en kompetisiegees van die Noord-Amerikaanse gemeenskap beïnvloed. Omdat die meeste deelnemers verbonde was aan een of ander para-kerklike organisasie, is die verwarrende vermeerdering van strukture net te maklik aanvaar. Daar is dikwels min pogings tot groter eenheid tussen hierdie groepe.)

Op hierdie manier is, soos reeds aangedui, 'n baie hoë mate van eenstemmigheid bereik. Soos baie min op internasionale kerklike byeenkomste gebeur, is daarin geslaag om hierdie groot skare te begeester en saam te bind met 'n gemeenskaplike visie. Ons moet weer ' $n$ keer herhaal dat daar by Manila slegs van 'deelnemers' sprake was, en nie 'afgevaardigdes' nie. Dit is relatief maklik om die ander as 'n medegelowige te aanvaar en te waardeer wanneer dit nie allerlei implikasies vir jou kerkverband of organisasie inhou nie. Hierdie ontspanne eenheid is legitiem en waardevol, maar is tog oppervlakkig as dit nie ook tot 'n ernstige soeke na groter strukturele eenheid lei nie.

Die vraag wat dus gevra moet word - al moet hy nie te gemaklik beantwoord word nie - is na die diepgang van hierdie eenheid. Was hierdie eenheid dalk bereik alleen in die mate wat die werklik verdelende sake vermy is?

Daar is pas melding gemaak van die dreigende kontrovers rondom die Charismata. Dit was een van die sake wat wel aangepak is, maar ook dft is nie werklik grondig uitgepraat nie en het by standpuntstellings gebly. Die nog moeiliker sake rondom die verstaan van die Skrif, en die interpretasie van die politieke en ekonomiese werklikheid, is nie aangeroer nie. Die sosio-politieke voorbeelde wat gereeld 
aangehaal is, was dié waaroor daar aanvaar kon word dat daar min verskil van opinie oor sou bestaan: sake soos die optrede van die Sjinese regering teen die studente betogers, burgeroorlog in Mosambiek, en ... die verwerping van apartheid!

Ek sê wel dat hierdie vraag nie te gemaklik beantwoord moet word nie. Is dit regtig so dat samekomste altyd benut (misbruik?) moet word deur dikwels onoplosbare probleme aan te pak? Die resolusies waartoe gekom word, is selde konsensus oplossings, maar meer dikwels feitlik 'n politieke oorwinning van een denk- of drukgroep oor 'n ander. Hierdie werkwyse, meer nog as die verskil van opinie, veroorsaak onenigheid en bitterheid.

Daar is dus gevare na albei kante. As Manila dit dalk vermy het om die moeilike sake in groot detail te bespreek, en so aan diepgang ingeboet het, is dit ook waar dat ander vergaderings - soos dié van die Wêreldraad - 'issues' dikwels te eensydig hanteer. Die voordeel van die Manila model is egter ook duidelik. Dit lei daartoe dat 'n groot klomp energie positief aangewend kan word vir die saak van die koninkryk van God, en dat 'n platform geskep kan word vir die uiteindelike oplossing ook van die ander sake.

\section{Verhouding met die WRK}

Ek het reeds gemeld dat daar vanaf die staanspoor die gevaar was dat die Lausanne-beweging sy identiteit sou vind as opposisie vir die WRK. Dit is inderdaad so dat die (Protestantse) kerklike toneel in 'n groot mate beskou kan word as 'n spanning tussen die twee benaderings of beklemtonings wat onderskeidelik deur hierdie twee organisasies verteenwoordig word. Maar gelukkig het die Lausannekomitee daarin geslaag om hierdie slaggat te vermy. Danksy ' $n$ hele aantal evangeliese leiers wat opbouende gespreksgenote van die ekumeniese beweging geword het, is daar baie getuienis dat hierdie kloof nie verdiep het nie, maar dat daar wedersydse beïnvloeding kon plaasvind.

Deur 'n sameloop van omstandighede het dit so gebeur dat die sporadiese groot sendingkonferensie van die WRK twee maande vór die Manila vergadering in San Antonio, Texas, plaasgevind het. Was daar ' $n$ wedersydse beinnvloeding tussen hierdie twee vergaderings? Het Manila die verhouding verder uitgebou, of het die teendeel dalk gebeur?

Die vergadering van die WRK te San Antonio, Texas is met geen woord in die volvergaderings by Manila genoem nie (behalwe een negatiewe opmerking oor die standpunt wat die voorsitter, Eugene Stockwell, op 'n stadium sou gestel het). Een werkgroep het egter die opdrag gekry om te reageer op 'n brief wat deur 'n groep afgevaardigdes van San Antonio, met amptelike medewete, aan die Lausanne II vergadering gerig is. 
Hierdie groep persone, meer as 150 in getal, het 'a letter of evangelical concerns' gestuur en veral die volgende beklemtoon:

* Hulle was verryk deur hulle deelname aan die aanbidding en ope bespreking van sake by die ekumeniese konferensie. Daar was talle insette waaroor hulle baie dankbaar was. Veral die pragtige dokument 'Mission and Evangelism - an ecumenical affirmation' uit 1982 is met vrug bestudeer. Hulle doen aan die hand dat die Lausanne-beweging ook ernstige aandag daaraan skenk.

* Dan noem hulle 'n aantal sterk punte van die evangeliese stroom 'which you bear as a gift and a trust for the worldwide body of Christ'. Hierdie insette is nodig vir die hele kerk. 'We urge that both the Lausanne Movement and the World Council avoid the temptations of mutually excluding each other's concerns from their public platforms and presentations.' Daarom gaan hulle so ver om 'n pleidooi te lewer daarvoor dat die volgende vergaderings, indien moontlik, op dieselfde plek gehou word, sodat daar direkte interaksie kan plaasvind.

- Die twee 'major concerns' wat hulle aan die Lausanne II vergadering sou wou oordra as terreine waarop daar in die toekoms gefokus sal moet word, is (a) die verhouding tussen evangelisasie en sosio-politieke betrokkenheid, en (b) die kommunikasie van die unieke Christus as Verlosser binne die konteks van die ontmoeting met mense van ander gelowe.

Genoemde werkgroep (wat aan die skrywe vanaf San Antonio moes aandag gee) het positief op hierdie brief gereageer en by die Lausanne komitee aanbeveel dat die Commission for World Mission and Evangelism (CWME) leierskap versoek word om by ' $\mathrm{n}$ toekomstige bespreking van die 'Ecumenical Affirmation' besondere aandag aan die vraagstuk rondom die uniekheid van Christus te gee, en om daarvoor ook 'n spreker met evangeliese oortuigings op die paneel te gebruik. Die moontlike verdere verloop van die saak is nie aan my bekend nie.

\section{Sosiaal-politieke betrokkenheid}

Die aktiewe en openlike deelname aan politieke aangeleenthede was die een saak wat tradisioneel tussen die 'evangelicals' en 'ecumenicals' gestaan het.

- Die evangeliese organisasies en individue het hulleself hoofsaaklik op evangelisasie toegespits, en min of meer van die veronderstelling uitgegaan dat verloste individue die onreg en onheil in die samelewing sal aanspreek. Hulle het gevoel dat betrokkenheid by sosiaal-politieke sake maklik veroorsaak dat die hoofsaak - die verkondiging van die evangelie - agterweë bly. 
Daar moet in gedagte gehou word dat die evangeliese stroom hoofsaaklik gedra is deur organisasies en persone wat met die taak van wêreldevangelisasie gemoeid is, hulle wat te doene het met persone wat of nog nie van Christus gehoor het nie, of Hom nog nie as Here aanvaar het nie. Hulle vrees is daarom verstaanbaar. Daarby het hulle ondervinding van die praktiese probleme om aan al die dimensies reg te laat geskied.

- Daarteenoor het die ekumeniese styl, veral sedert die sestigerjare, daartoe gelei dat baie eksplisiet in die sake van die dag betrokke geraak is. Waar eersgenoemde hoofsaaklik die 'vertikale' en persoonlike dimensie van verlossing uit sonde beklemtoon het, het laasgenoemde dan beklemtoon dat sonde en verlossing (bevryding) ook (en veral) 'n horisontale en strukturele dimensie het. Dit sou nie help om alleen maar persone aan te spreek nie. Daar is sondige stelsels en omstandighede wat reggestel moet word.

Anders as die evangeliese beweging is die ekumeniese beweging gedra deur amptelike afgevaardigdes van kerke. Die agenda in gevestigde kerke is meestal anders as dié van sendingorganisasies. Hier is dit nie mense wat primêr oor die bereiking van nie-Christene nadink nie, maar Christene wat bekommerd is oor die Christelike getuienis van kerke in die samelewing. Hulle is bekornmerd oor hulle skuld aan wantoestande, en vra vrae oor moontlike optrede om die skade reg te stel. Hulle dink primêr aan die geloofwaardigheid van die kerk.

Soos die mens dikwels nie in staat is om die spanning tussen aanvullende skynbare uiterstes in balans te hou nie, het die twee beklemtonings gaandeweg gepolariseer geraak en gedreig om al meer in die eensydighede op te gaan. Het Manila bygedra tot die verdere polarisering, of nie?

Ek meen dat met blydskap gekonstateer kan word dat - geoordeel volgens die verloop van sake in die Manila-byeenkoms - hierdie ongelukkige en onnodige stryd grootliks tot die verlede behoort. Waar die 'Lausanne Covenant' in 1974 met groot versigtigheid die beginsel van die noodsaaklikheid van sosiale betrokkenheid in die sending gestel het, en hierdie stelling aanvanklik een van die groot interne debatspunte was, het die hele bespreking en gees van Manila (soos ook geformuleer in die Manila Manifesto) rustig van hierdie beginsel uitgegaan. Die saak is nie meer ter sprake nie. Wat nou aandag geniet, is die hoe van die betrokkenheid by die nood van die wêreld: hoe kan betekenisvol aan die nood aandag gegee word sonder om die vertikale dimensie prys te gee?

Die ekumeniese beweging het inderdaad by dieselfde punt aangekom, al is dit dan van die teenoorgestelde kant af. Hulle vraag is: hoe kan die volledige betrokkenheid ook Christelik bly? Daarom is daar mooi moontlikhede vir opbouende dia- 
loog hieroor. Net soos wat daar by sommige' $n$ ontevredenheid is oor die wyse waarop Manila die 'issues' hanteer het (of nie hanteer het nie), is daar 'n onrustigheid by ander oor die ongebalanseerde wyse waarop San Antonio dit gedoen het. Dit bly egter steeds 'n dringende saak om te weet hoe om die implikasies van die 'whole gospel in the whole world' uit te leef.

Wat wel miskien die ernstigste leemte in die Manila vergadering aangemeld moet word, is die totale afwesigheid van die ekologiese dimensie uit die program. Dat die ontwikkelingsproblematiek nie eksplisiet aan die bod gekom het nie, kan nog vergewe word, want verwante sake soos sosiale betrokkenheid, die armes, eenvoudige lewenstyl, en ander soortgelyke onderwerpe het wel aandag geniet. Maar dit is ' $n$ ernstige oorsig dat aan die kerk en die evangelie se betrokkenheid by ekologiese vraagstukke geen ruimte gegee is nie. Dit is te meer onvergeeflik omdat hierdie tema reeds in die ekumeniese beweging in die sentrum te staan gekom het, soos die komende kongres oor 'Justice, peace and the integrity of creation' (JPIC) aandui. Dit versterk die indruk dat, anders as die ekumeniese beweging wat uitgaan van die omvattende skeppingsparadigma, die evangeliese stroom nog 'n groot preokkupasie met die sondeval vertoon. Laasgenoemde is sekerlik baie belangrik, maar die breër raamwerk mag nie gemis word nie.

\section{Uniekheid van Christus}

Die ander tema wat genoem is in die brief vanuit San Antonio, en die een wat vorentoe seker nog meer in belangrikheid gaan toeneem, is die verkondiging van Christus aan mense van ander godsdienste (kyk o a ook Bosch 1989:131). Wat is die betekenis van Christus buite die Christendom? In watter mate is daar 'verlossing' binne die ander godsdiente? Kan hulle ook Christus binne hulle gods-dienste vind en aanhang? Wat van hulle wat Christus nie aangeneem en lidmaat van 'n kerk geword het nie?

Tot dusver was die antwoord van die 'evangelicals' baic eenvoudig: extra ecclesiam nulla salus - dié wat nie bewustelik deur die geloof Christus aanneem, en aan sy kerk behoort nie, is verlore. Al sou hierdie antwoord moontlik reg wees (en dit lyk tog na die oorweldigende getuienis van die Nuwe Testament), is die antwoord tot dusver taamlik probleemloos aangebied. Ook by die Manila vergadering het die onderwerp van die godsdienstig plurale wêreld en die uniekheid van Christus ter sprake gekom, maar in geen diepte nie. Dit lyk asof die heersende ietwat fundamentalistiese benadering tot die Skrifopenbaring bepaalde grense stel aan die vraagstellings in hierdie sake.

Eerder is Manila gekenmerk deur die tipies triomfalistiese selfversekerdheid wat so algemeen in die sendingaksie vanuit Noord-Amerika was en nog steeds is. 
Hier word die energie nie bestee in die beantwoording van moeilike teologiese (en kwasie-teologiese) vrae nie, maar in die ontwerp van planne om die hele wêreld teen die jaar 2000 te bereik.

In teenstelling daarmee is daar in die ekumeniese beweging by tye so 'n geloofwaardigheidskrisis en skuldgevoel (anti-triomfalisme) in eie geledere dat die klem eerder op Christus extra muros ecclesiae begin val het: Christus werk tog sekerlik nie net binne die kerk nie, maar op dikwels onbekende wyses ook in die ander godsdienstige gemeenskappe! Mense kan 'Christene' wees sonder dat hulle dit weet, of selfs wil weet! In stede van verkondiging is dit meer gepas om in ootmoed dialoog met die aanhangers van die ander godsdienste te voer, as gemeenskaplike soekers na die waarheid van verlossing.

'n Bepaalde hermeneutiek sou dit ook heeltemal geoorloof maak om redelike veronderstellings buite die Skrif om te maak, op grond van wat wel met die Christelike rede sou strook. Ook die openbaring van God kan tog nie tot die Bybel beperk word nie, word geredeneer. Waarom kan die ander godsdienste nie ook voorbereiding vir die evangelie wees nie?

Alhoewel hierdie relativistiese benadering skynbaar nie meer die hoofstroom verteenwoordig nie, is daar nog heelwat onbeantwoorde vrae.

Die verskille tussen die twee Protestantse strome rondom die politieke betrokkenheid is inderdaad nie meer so ingrypend nie, maar op hierdie laasgenoemde terrein is daar nog groot verskille van uitgangspunt. Die toekomstige interaksie sal baie belangrik wees.

Die 'owerhede en magte'

Dit was die teologiese benadering wat met die Bevrydingsteologie vereenselwig kan word wat die aandag begin vestig het op die strukturele dimensie van die kwaad. Sonde gaan skuil in strukture. Dit is nie genoeg om slegs maar die persoonlike sonde in individue aan te spreek nie. Die stryd is ook teen die 'owerhede en magte' (Ef 6:12). Paulus, so word daar gemeen, het hier kennelik die politieke en ekonomiese 'strukture' van die wêreld in gedagte gehad - daardie magte wat 'n mens se lewe 'maak'. Daarom het die bevrydingsteoloë, maar ook ander van soortgelyke oortuiging, op groot skaal betrokke begin raak by politieke en ekonomiese aangeleenthede. Die magte moes ontmasker en 'ontmag' word.

Die tradisionele evangeliese benadering was, soos reeds gesê, anders. Die persoonlike element het nog prioriteit geniet, en die verkondiging van die evangelie.

Allan Tippett van die Fuller School of World Mission, senior kollega van die Church Growth man, Donald McGavran, het egter reeds in die vroeë sewentigerjare met die konsep van die 'power encounter' gekom. Dikwels, so het Tippett gevind, 
toon 'n stam geen toenadering tot die evangelie nie, totdat op 'n bepaalde tydstip daar 'n konfrontasie plaasvind, waartydens Christus as 'sterker' as die 'afgod' bewys word. Dan is die weg gebaan vir die oorgang tot die Christendom. So 'n konfrontasie, al is dit ook hoe noodsaaklik, kan uiteraard nie deur die sendeling 'gereël' word nie, maar moet nie vermy word nie, en kan alleen met ernstige gebed aangepak word. In die jongste tyd word dan ook baie gemaak van 'geestelike oorlogvoering' deur die gebed. Die werklikheid van die Sataniese invloed in die samelewing begin al groter erkenning geniet. In watter mate is die voorheen waargenome weerstand teen die evangelie die gevolg van die rol van die plaasike afgode en demone? Is dit nie opvallend nie dat die vroeë kerk deur die 'wonders en tekens' (Hand 2:43) van die apostels gegroei het, word gevra?

Op hierdie manier het die evangeliese sendingwetenskaplikes en sendelinge ook op groot skaal met die 'owerhede en magte' begin kragte meet. Al sou hulle dit nie soseer die 'strukturele' dimensie noem nie, maar die 'demoniese', is hier baie beslis 'n hoogs belangrike veld waar gesamentlike navorsing in die toekoms onderneem behoort te word.

\section{Op weg na $2000 \mathrm{nC}$}

Daar is geen twyfel dat die bereiking van al die mensegroepe van die wêreld met die evangelie 'n onvervreembare doel van die kerk van Christus moet bly nie. Die blote feit dat volgens die mees optimistiese berekeninge (Barrett 1982:18) slegs ongeveer $75 \%$ van die wêreldbevolking 'geëvangeliseer' is, behoort die kerk tot doelgerigte aksie te beweeg. (Volgens dieselfde berekeninge is ongeveer $33 \%$ 'Christene'.)

Vroeg in die eeu is die slagspreuk 'the evangelisation of the world in this generation' dikwels gebruik. Die aangrypende waarheid daarvan lê in die oproep wat daarin opgesluit is: elke geslag mense kan alleen deur hul tydgenote bereik word!

In die jongste jare het die komende jaar 2000, die ingang in 'n nuwe millennium, mense begin aangryp. 'Die evangelisering van die wêreld voor die jaar 2000' het nou die slagkreet geword. Talle planne om juis dit moontlik te maak, is in die afgelope tyd deur verskeie sendingorganisasies en kerke opgestel en gepubliseer (vir 'n oorsig daaroor, kyk Barrett \& Reapsome 1988; Wang 1989).

By Manila het hierdie 2000 n C-beweging baie aandag geniet. Trouens, die Internasionale Direkteur van die Lausanne-beweging. Thomas Wang, het juis die tuig neergelê om meer aandag daaraan te gee. Van twee kante af is daar versigtige kritiek uitgespreek teen die ' $2000 \mathrm{nC}$ sindroom'. 
- Daar is gewaarsku teen sodanige fiksering op 'n bepaalde datum. Ten slotte sal dit tog maar 'n doodgewone sonsopkoms wees! En: wat van die dae en jare (en selfs moontlik die eeue) ná die magiese jaartelling? Daarom het die leiers liewer begin praat van die evangelisering van die wêreld teen 'AD 2000 and beyond'.

- Persone uit die Tweederde Wêreld en uit Oos-Europa is baie sensitief vir die triomfalistiese klank inherent aan so 'n program wat amper soos 'n veldslag met militêre presisie beplan en deurgevoer wil word. Die hele arsenaal van Bybelse beelde en uitsprake wat dui op die stille en opofferende werking van die koninkryk van God word hierteen aangehaal.

Die ekumeniese stroom neem (na my wete) nie aan hierdie debat deel nie. Moontlik interesseer dit hulle nie. Moontlik fokus die agenda nog te veel op ander dinge. Hoe dit ook al sy, die doelgerigte aanpak van die groot onvoltooide sendingtaak in die wêreld mag nie deur die twyfel oor terminologie en styl aan bande gelê word nie. Dit pas die kerk om oral die entoesiasme vir hierdie taak te herwin.

\section{Literatuurverwysings}

Allan, J D 1989. The evangelicals: An illustrated history. Exeter: Paternoster.

Barrett, D B (ed) 1982. World Christian encyclopedia. London: Oxford University Press.

Barrett, D B \& Reapsome, J W 1988. Seven hundred plans to evangelize the world: The rise of a global evangelization movement. New Hope.

Bosch, D J 1989. Your will be done? Critical reflections on San Antonio. Missionalia 17/2, 126-138.

Douglas, J D 1975. Let the earth hear his voice: International congress on world evangelization. Minneapolis: World Wide Publications.

Wang, T (ed) 1989. Countdown to AD 2000. Pasadena: William Carey Library. 